\title{
Evidence for Mesolithic agriculture in and around central Europe?
}

\author{
Karl-Ernst Behre
}

Received: 8 March 2006 / Accepted: 11 July 2006 / Published online: 21 October 2006

(C) Springer Verlag 2006

\begin{abstract}
A critical assessment of the data recently put forward in favour of a 'Mesolithic agriculture' for Central and Northern Europe is presented. The archaeobotanical record is quite clear: hundreds of excavations of early Neolithic sites, whether from Linearbandkeramik or Trichterbecher (funnel beaker) settlements have produced remains of cultivated plants in large numbers. In contrast to this, all Mesolithic sites excavated so far have not revealed even one macroscopic find of crop plants. The 'Mesolithic agriculture' as assumed by several authors, is based solely on single pre-Neolithic pollen grains of the Cerealia-type that occur in pollen diagrams. It is shown that absolute distinction of pollen from wild grasses and cereals is impossible. There is a certain overlapping of both types that must not be neglected. Because of the large pollen sums in modern pollen diagrams, even very scarce grains of Cerealia-type pollen are encountered. Most of these single pre-Neolithic grains must derive from native wild grasses, while others come by long-distance transport etc. Another important feature is the scattered occurrence of Cerealia-type pollen grains from the early Holocene (or even Pleistocene) to the start of the Neolithic. They do not occur in synchronous phases and even in neighbouring sites they do not agree in age. As long as there are no well-dated macro-remains of crop plants of pre-Neolithic age, there is no evidence of Mesolithic agriculture.
\end{abstract}

Keywords Pollen analysis - Mesolithic agriculture Cereals $\cdot$ Neolithic $\cdot$ Europe

Communicated by S. Jahns

K.-E. Behre $(\bowtie)$

Niedersächsisches Institut für historische Küstenforschung,

Viktoriastrasse 26-28,

26382 Wilhelmshaven, Germany

e-mail: behre@nihk.de

\section{Introduction}

The discussion of earliest agriculture is almost as old as archaeology itself. The transition from hunting, fishing and gathering to farming marks the beginning of the Neolithic period. This was the most important change in the history of humanity and is connected with the start of permanent settlements, having profound consequences for ecology as well as economy.

The question of how this change took place has been vigorously debated in many publications. While the origin of agriculture in the Fertile Crescent was a long and continuous process, two different processes have been proposed for the transition from foraging to farming in Europe. One is colonisation by immigrants who brought domesticated crop plants with them and the adoption of this fully developed agricultural system by Mesolithic people, as is mostly assumed for the start of the Linearbandkeramik. The other is a slow and gradual process of adoption as in the model of Zvelebil (1996) for the circum-Baltic region. While finds of carbonised remains of cultivated plants are the most reliable source for tracing the oldest arable farming, pollen analysis can also contribute to this question. There are several Mesolithic records of single pollen grains of Cerealia-type which have been interpreted as indicators of earliest agriculture. This, however, has to be done very cautiously, because not every pollen grain of this type really derives from cereals. For a long time there has been intense competition between scientists to find the earliest, the northernmost or the highest-altitude cereal cultivation and they sometimes jump to premature conclusions.

In recent times there have been an increasing number of publications in which 'Mesolithic agriculture' is claimed solely on the basis of single finds of Cerealiatype pollen grains. Starting with the early paper of 
Kossack and Schmeidl (1975), there are other examples from Erny-Rodmann et al. (1997), Richard (2004) or the survey article of Gehlen and Schön (2003). The latter authors have recently written of the "mittlerweile regelhaften Nachweis der 'spätmesolithischen' Getreidenutzung in alpinen und circumalpinen Gebieten" (meanwhile regular evidence of 'late Mesolithic' use of cereals in the Alpine and circumAlpine regions). The concept of 'Mesolithic agriculture' has meanwhile become a self-propagating idea and has already also found acceptance in general monographs such as Lüning (2000). This cannot be left unchallenged and the basic data for the 'Mesolithic agriculture' have to be checked thoroughly. As result of long discussions with botanical colleagues, the author was encouraged to write a critical assessment of the data and their interpretation with regard to possible Mesolithic agriculture. This has been done here.

\section{Quality of material and dates}

\section{Reliability of identification}

The assumption of 'Mesolithic agriculture' is based solely on the occurrence of Cerealia or Cerealia-type pollen in the respective levels of pollen diagrams. Therefore the reliable identification of these pollen grains is essential.

Firbas in his landmark paper of 1937 was the first to separate wild grass-type pollen and Cerealia-type pollen by means of size measurements. Since then several thorough studies have been undertaken in order to divide both groups and to find additional characteristics to distinguish the $\mathrm{Ce}$ realia pollen (e.g. Beug 1961, 2004; Andersen 1979; Köhler and Lange 1979; Moore et al. 1991). For pollen treated by acetolysis and mounted in glycerine, the boundary between wild grass-type and Cerealia-type was placed at $40 \mu \mathrm{m}$, but several other features have also to be used for this separation.

The latest key of Beug (2004) proposes four criteria, which have to be fulfilled to classify a pollen grain as Cerealia-type:

According to this definition pollen from cultivated species of Panicum, Setaria and Sorghum still partly belong to the wild grass-type.

\begin{tabular}{ll}
\hline largest diameter & $>37.0 \mu \mathrm{m}$ (in order to include at least $98 \%$ of \\
& $\begin{array}{l}\text { Triticum, Hordeum and Avena species); in } \\
\text { pollen analysis a boundary of } 40 \mu \mathrm{m} \text { is }\end{array}$ \\
& generally applied \\
pore diameter & $>2.7 \mu \mathrm{m}$ \\
anulus width & $>2.7 \mu \mathrm{m}$ \\
anulus thickness & $>2,0 \mu \mathrm{m}$ (mostly $3.0 \mu \mathrm{m})$
\end{tabular}

Apart from cultivated cereals, the following species belong at least partly to the Cerealia-type (some southern species are also included; taxonomy following Beug 2004):

\begin{tabular}{ll}
\hline Aegilops ovata & Glyceria plicata \\
Agropyron caninum & Hordeum murinum \\
Agropyron intermedium & Lygeum spartum \\
Avena fatua & Secale montanum \\
Bromus erectus & Setaria glauca \\
Bromus inermis & Setaria pumila \\
Bromus mollis & Triticum aegilopoides \\
Glyceria fluitans & Triticum dicoccoides \\
\hline
\end{tabular}

(halophytes and dune grasses are not listed here)

Of these species mainly the Bromus species as anthropogenic indicators, and the Glyceria species, growing in wet habitats often used for pollen profiles, can be expected in Central European pollen diagrams. More species occur in coastal regions.

An additional method of identifying Cerealia pollen is the use of phase contrast microscopy. This was first employed by Grohne (1957) and further developed by Beug (1961, 2004). Phase contrast provides additional characteristics from the fine structure of the pollen wall and helps to distinguish certain types. These types, however, also include some common wild grasses together with the cultivated forms. So the Hordeum-type includes among others four wild Hordeum species and at least in part three species of Agropyron as well as Bromus and the crucial Glyceria species. Also the important Triticum-type includes some pollen grains of wild Hordeum and Bromus species.

Old pollen diagrams were prepared without employing phase contrast microscopy and even some modern diagrams do not use this method. Often the examination of critical pollen grains is difficult because they are crumpled or ruptured, or they are compressed and the structures of two exines with their different pattern of columellae in phase contrast are seen in the same level. This means that good preservation of the fossil pollen is necessary and an experienced palynologist is needed. Not all pollen diagrams fulfil these preconditions. But even for experienced analysts an accurate identification of a Triticum- or Avena-type pollen grain is often difficult. So not every grain named Triticum-type in a pollen diagram really is one.

The combination of size and phase contrast characteristics improves the identification but there is no final certainty. Therefore the addition of the suffix -type is always necessary. Single pollen grains of the Cerealia-type mean very little, but larger numbers in a sample support identification as Cerealia.

In order to check the possibility of identification of Cerealia pollen types, Tweddle et al. (2005) tested the keys of Andersen (1979) and Küster (1988) using a large Holocene 
dataset from England. Here, in the region of NW Europe, they were sure that all large Poaceae pollen grains, at least from before 6800 B.P. (5700 cal B.C.), must come from wild grasses. This predates the generally accepted date for the establishment of the Linearbandkeramik culture in mainland Europe (Lüning 2000), while arable farming was introduced in Britain much later still. By applying these pollen keys, it turned out that about a quarter of the large pollen grains remained unclassified because they did not have the required characteristics; however the majority were classified as Hordeum-type or Triticum- and Triticum-Avena-type respectively. This shows clearly the difficulties and uncertainties in the identification of single Cerealia pollen grains. On the other hand, Tweddle et al. (2005) showed that, if a large number of pollen grains are available (for fossil material this means from a certain horizon) the employment of principle component analysis, together with discriminant analysis, is very helpful for a reliable separation of the different Cerealia types.

Another problem, as yet not really investigated, is the spontaneous polyploidisation of wild grasses, which leads to the development of large pollen grains. These are in the size range of Cerealia and certainly contribute to the records of large Poaceae pollen.

All these difficulties of identification are small if compared with those in the Near East. In that region, where alongside other grasses there live the ancestors of the most important European cereals, distinction of Cerealia is impossible. There Cerealia-type percentages give only limited hints of agrarian activities. This type is already frequent at 15,000 years B.P., but occurs even earlier (Bottema 1992).

While it is now well known that in the Near East distinction between wild grass and cereal pollen is impossible, there has been discussion of this problem for South Asia. There also a pre-Neolithic agriculture had been postulated. It turned out, however, that here too, the large Cerealiatype pollen grains recorded from the late Weichselian and early Holocene had to be attributed to several genera of wild grasses (Vishnu-Mittre 1981).

The similarity of the pollen of some wild grasses to Cerealia can also be demonstrated in another way: there are quite a number of Central European pollen diagrams covering the Pleistocene where Cerealia-type pollen is recorded, sometimes even as a curve. So for instance Peschke (1983) presents a curve from the interglacial Schieferkohlen Hernhausen/Upper Bavaria (together with a curve of Plantago lanceolata). Also the author himself (in Behre and Lade 1986) found altogether 34 pollen grains of the Cerealia-type (mainly around $50 \mu \mathrm{m}$ but up to $58 \mu \mathrm{m}$ in size) in certain lacustrine layers from the early Weichselian Brörup and Odderade interstadials at Oerel/N Germany. These finds confirm the overlapping of pollen from wild and cultivated grasses.
With respect to the increasing number of finds of single pre-Neolithic Cerealia-type pollen grains, another point has to be taken into account. This is the number of grains inspected. In modern pollen diagrams often more than 1000 pollen grains per sample are counted and by employment of rapid scanning of additional slides even a multiple of this. In closely spaced pollen diagrams with a fine time resolution hundreds of thousands of grains are inspected, including many grasses. This means that even extremely rare pollen, be it from long-distance transport or contamination, can be detected. In the case of wild grasses, specimens with a diameter beyond the size range of the 150 measurements made by Beug (2004) or 100 made by Andersen (1979), as well as others with unusual pores or surface structure, are also encountered. This means that the increasing chance of tracing real cereal pollen by high counts includes, on the other hand, the 'danger' of finding unwanted grains.

With regard to macroscopic remains of cultivated plants, the reliable identification of cereals hardly ever creates problems and in Europe there are no possibilities of confusion with wild grasses. Separation of wild and cultivated forms of other crop species may, however, be difficult.

At this point the postulated earliest occurrence of cultivated linseed (Linum usitatissimum) must be mentioned. There is one record of a seed, found at WallisellenLangachermoos in Switzerland, which is dated to the Mesolithic and in literature repeatedly taken as principal evidence of pre-Neolithic agriculture (Haas 1996). However seed measurements of several wild Linum species showed that the size of the seed in question is well within the range of these wild species and therefore there is no reason to regard this specimen as cultivated (Table 1).

\section{Reliability of dating}

With respect to pollen analysis, the main subject of this article, radiocarbon is the most important absolute dating method. This is not the place to describe the advantages and difficulties of this method; however, the possibilities of erroneous dates that are often underestimated must be borne in mind. Invisible contamination by tiny roots or re-deposited material is the most frequent source of errors for conventional as well as AMS-dating. In lake deposits the hard water effect may produce strong deviations in age that are not always considered. Also laboratory errors are possible.

The certain and synchronous context of the dated material with the archaeological object is very important. A warning example is the discovery of cultivated barley around 18,000 years B.P. in southern Egypt, which led the authors (Wendorf et al. 1979 in the well known journal SCIENCE) to shift the origin of agriculture into this region. In this case charcoal from a Mesolithic site, associated with neolithic barley, had been dated. After the development of the AMS-method the 
single barley grains themselves were dated and gave an age around 4850 years B.P. (Wendorf et al. 1984) so that the origin of first food production returned to the Fertile Crescent.

One has also to be careful with uncalibrated dates, which in earlier days are sometimes also expressed as B.C. (v. Chr. in German, e.g. Küster 1988).

To sum up: single ${ }^{14} \mathrm{C}$ dates, on which many of the earliest Cerealia-pollen grain finds depend, are often not as reliable as they are assumed to be.

\section{Problems of contamination}

The possibility of contamination starts at sampling, be it by coring or excavation. Atmospheric pollen as well as disturbances like bioturbation and other sources must always be considered.

The following is an example from early records of buckwheat: in six out of seven pollen diagrams from raised bogs in NW Germany, Mohr (1990) found in his cores single pollen grains of Fagopyrum from the beginning of our era onwards, that is more than 1000 years earlier than expected, but he had no explanation for it. In this case the explanation is easy, because these bogs were used for buckwheat cultivation from the 17th until the 19th century. During coring with the Hiller sampler single pollen grains must have been displaced.

Other sources of contamination may arise in the lab during sampling and preparation. Apart from dirty glassware (which of course nobody uses) even here pollen in the air can never be completely excluded.

\section{Long-distance transport}

Long-distance transport of Cerealia pollen is often not accepted as a source of error, but it should be. Wind transport of cereal pollen, however, is only limited, because the old cereal species are self-pollinating and most of the pollen grains remain in the glumes being released mainly during harvesting and threshing (Vuorela 1973; Behre 1981).

More important than the Cerealia themselves in longdistance transport are the Cerealia-type wild grass pollen grains from the Near East and the eastern Mediterranean that cannot be distinguished from the cereals (see above). According to the investigations of Bottema (1992) Cerealiatype pollen found in the subfossil record in the Near East seldom seems to be produced by wild or domesticated cereals, especially wheat. It is derived from several other wild Poaceae which release their pollen while flowering.

Almost every year there are weather situations during which considerable amounts of dust from the Sahara and other regions are blown to Central Europe - clearly visible on our cars. This dust also contains pollen. These genera are shown in their Late-glacial or Holocene pollen diagrams by various authors who are familiar with African pollen. So for instance Drescher-Schneider (1993) noted pollen of $\mathrm{Ce}$ drus, Moltkiopsis ciliata, Calligonum and Lygeum spartum, nowadays growing only in North Africa and the Near East, in her sites from the southern Alps. Bortenschlager (1965) had already earlier recorded African pollen in Alpine glaciers.

Almost every palynologist recognises the easily determinable pollen types of Ephedra that sometimes occur in Holocene deposits and accepts their African or Mediterranean origin. Other exotics remain unidentified and are included in varia. There is, however, almost no discussion of single Cerealia-type pollen grains from Boreal or Atlantic times and whether they might have been blown in by long-distance transport like other pollen. Supporters of preNeolithic agriculture regard them as of doubtless local or regional origin and to be evidence of cereal cultivation (see below).

Context with other anthropogenic indicators

The joint occurrence of Cerealia-type pollen with so-called secondary anthropogenic indicators in pollen diagrams is taken as a very important signal for the recognition of agrarian settlements. However, the importance of these occurrences is sometimes overestimated, when the curves of these indicators are only weak. One must always bear in mind that many of the common anthropogenic indicators are native plants, in particular those species that can be traced by pollen analysis. As so-called apophytes they occur naturally in small habitats or niches and were favoured by the activities of man when he opened the landscape or created ruderal stands that were occupied by nitrophilous species (Behre 1981, 1986).

Small quantities of these species do not necessarily indicate farming, in particular if they are not synchronous. Even in dense forests there are sometimes temporary small open spaces and these are frequent along rivers, at bog edges and particularly in mountainous areas and along the coasts. So for instance even the most important anthropogenic indicator - Plantago lanceolata - was not introduced from elsewhere but has its home also in Central Europe. This can be shown by its occasional occurrence in interglacial pollen diagrams (e.g. Behre 1962; Peschke 1983; Bittmann 1992) and by its sporadic occurrence in the Late-glacial and early Post-glacial. Küster (1988) presented a map with these records and emphasized that Plantago lanceolata must be indigenous; another map for Poland shows rare but continuous records there from 7500 B.P. or 6340 cal B.C. (Makohonienko et al. 2004). Other taxa such as Chenopodiaceae, Artemisia and Rumex, to name just a few, are often frequent in the Late-glacial and early Holocene. They may indicate natural openings as well as suitable stands around settlements, where on anthropogenic eutrophic ground in particular ruderals are present. Also natural or man induced (already by 
the Mesolithic) forest fires create and maintain a diversity of these species. All these features are not necessarily accompanied by cereal cultivation. Therefore the assessment of anthropogenic indicators has always to be done with great care.

\section{Discussion of regional records}

\section{Northern Germany and Denmark around the Baltic}

In the Baltic region in northern Germany and in Denmark there is a long-standing discussion as to whether during the late Mesolithic Ertebölle culture there (5100-4100 cal B.c.) a limited cultivation of cereals was already practiced. This assumption is based on several single pollen grains of Cerealiatype, which in some older pollen diagrams are recorded before the elm decline during the period of the Ertebölle culture. The data given for Germany are based on analyses from the Wellsee near Kiel, where Schütrumpf (1951) noted two such pollen grains in the Mesolithic part of the diagram, which however he ignored in his text. Several further finds from pre-Neolithic layers, to which later publications always refer, are mentioned by Schütrumpf (1972) from Rosenhof and Satrupholmer Moor as well as by Kalis and Meurers-Balke (1988 - pollen diagram from the Rosenhof 1975 excavation with 2 photographs of pollen grains, $45 \mu \mathrm{m}$ in diameter).

From Denmark the pollen diagram Ordrup Mose near Copenhagen (after Iversen 1949, recalculated by Kalis and Meurers-Balke 1998) shows single Cerealia-type pollen grains in 2 samples below the elm decline. Another diagram from Trundholm (Kolstrup 1988) indicates 6 pollen grains of the Cerealia-respectively Hordeum-type before the elm decline; in this case the author took also wild grasses into consideration.

Referring to these records, Kalis and Meurers-Balke (1998) assume that "in Ostholstein cereal cultivation was already being practised as early as the beginning of the 5th millennium B.C., whereas in Denmark cereal cultivation cannot yet be traced back earlier than to ca. 4200 B.C."

Modern pollen diagrams with fine time resolution and count numbers, all analysed using phase contrast, do not confirm these finds. In spite of very close sampling intervals and high counts ( $>1000 \mathrm{AP} / \mathrm{sample}$ ) the standard diagram from the Belauer See in eastern Holstein (Wiethold 1998) shows just two grains of the Cerealia-type, moreover in a position 650 years below the elm decline, which means before the late Ertebölle. The settlement layers of the Ertebölle phase of Schlamersdorf, $25 \mathrm{~km}$ further to the south and the corresponding layer in the pollen diagram nearby do not contain any pollen of the Cerealia-type (W. Dörfler, pers. comm.). But even if single pollen grains of these types had occurred this wouldn't justify the assumption of arable farming.
Also the slightly older but high resolution pollen diagrams from Ostholstein, from the Plöner See (Averdieck 1974, 1978) and from around Bad Oldesloe (Averdieck 1990), show pollen of Cerealia-type only in the Subboreal period, that is after the elm decline, in Neolithic or Bronze Age times. Further to the east there are several diagrams from the island of Rügen, none of them showing Cerealiatype pollen before the Neolithic period. Cerealia-type pollen is also lacking in the analyses from the settlement layers at Lietzow-Buddelin on the island of Rügen (Lange et al. 1986; Endtmann 2005). This settlement of the so-called Lietzow group corresponds to the younger Ertebölle culture in the west and is dated between 4450 and 4050 cal B.c. (Terberger and Seiler 2005). Furthermore the cultural material of this group has a full Mesolithic character.

Up to the present there have been no finds of macroremains from cereals or other cultivated plants in the North German - Danish Baltic region for the time before 4100 cal B.C. The first single grains of cereals are recorded from Wangels (near Oldenburg i. H., site LA 505, H. Kroll, pers. comm.). They include the imprint of an emmer grain in a potsherd, published by Hartz et al. (2000). Also, according to Hartz (1999), fragments of querns were found. On the basis of numerous ${ }^{14} \mathrm{C}$ dates this site is placed into time phase $\mathrm{B}$, after Hartz et al. (2000), the Wangels group, which represents the earliest funnel beaker culture in eastern Holstein and is dated between 4100 and 3900 cal B.C.

Also with respect to pottery the Neolithic started here at that time. It should be mentioned that thick-walled pottery had already become common in the younger Ertebölle period and is not regarded as a Neolithic feature. However, around 4100 cal B.C. there is a considerable change in the pottery to better quality with more variety and decoration. This is the onset of the funnel beaker (Trichterbecher) culture, which turned out to be considerably younger here than previously assumed (Schwabedissen, 1994; Hoika 1994). The start of the funnel beaker culture in this region could be corrected from 4400 to $4100 \mathrm{cal}$ B.C. through new AMS ${ }^{14} \mathrm{C}$ dates of meal residues from potsherds (Hartz and Lübke 2005). The finds of carbonised cereal grains that appear from now on correspond in time with the records of Cerealia-type pollen at Siggeneben-Süd (Meurers-Balke 1983). On the basis of radiocarbon dates Meurers-Balke and Weninger (1994) originally placed this Siggeneben group between 4040 and 3700 cal B.C., but according to new dates it is now placed into the period 3900 to 3500 cal B.C. (Hartz et al. 2000). The pottery of Siggeneben-Süd also unambiguously points to the early phase of the Neolithic funnel beaker culture.

Several excavations, particularly underwater explorations in the Wismar Bay (Lübke 2005), have been carried out in recent years and have provided new archaeological evidence for the start of the Neolithic in this area. The results of these activities along the southern Baltic coast were compiled by 
Hartz et al. (in press), who in summary stated "Until ca. 4100 cal B.c. the economy was regularly based on aquatic/marine resources (fish and seals) and on terrestrial hunted game. Gathering of plant food such as hazelnuts can often be proved and contributed to a stable economic situation in Mesolithic tradition." From 4100 cal B.c. onwards the authors "see a change in the economy to domesticated animals and the use of cereals, but the latter were of limited relevance."

To sum up: for the Baltic region in Northern Germany and Denmark neither the botanical nor the archaeological evidence supports the assumption of pre-Neolithic agriculture (i.e. before $4100 \mathrm{cal}$ B.C.).

\section{Scandinavia and Eastern Central Europe}

In southern Sweden and Norway, as in Denmark, the start of arable farming took place around $4000 \mathrm{cal}$ B.C. Further to the north there was an increasing delay in Neolithic settlement. As in Central Europe there is quite a number of pollen diagrams with single pollen grains of the Cerealia-type that precede the archaeological evidence by several hundred years, and based on these records some authors claim evidence of early arable farming. In this case it was not the concept of 'Mesolithic agriculture' but the idea of an earlier start of the Neolithic than proven by archaeology so far. After a first critical and much debated contribution by Bjerck (1988), another evaluation of these data has recently been presented by Rowley-Conwy (1995), which made 'the first farmers younger'. I refer to these papers for the reasons shown in the preceding section. As has been illustrated in the model of Zvelebil (1996), farming practices and the position of the agricultural frontier moved only slowly to the North. The first farmers also kept on hunting and gathering until the historic period, and in the far North the foragers eventually became reindeer herders.

To the east also, in the Baltic countries and Finland, there is a marked delay in the spread of agriculture from south to north. The first finds of macroscopic cereal grains in Lithuania are from 3000 cal B.C., in Latvia and Estonia from around $2700 \mathrm{cal}$ B.C. and in Finland from after $2100 \mathrm{cal}$ B.C. (Poska and Saarse 2006). As in other regions, Cerealia-type pollen grains already appear in some pollen diagrams much earlier. In their paper on eastern Estonia (Akali) from 2006 Poska and Saarse mention the earliest finds of Triticum-type pollen, which date to $5600 \mathrm{cal}$ B.C. and interpreted them "as possible indications of the acquaintance of foragers with farming products". Several scattered pollen finds of various Cerealiatypes from 4900 cal B.C. were taken as marking the beginning of the Estonian Neolithic; this is 2200 years before the first cereal macro-remains in this country. In view of the difficulties in the proper identification of Cerealia pollen, this is most unlikely.
In Poland there is no discussion about 'Mesolithic agriculture'; single first Cerealia-type pollen grains are attributed to wild grasses, others are explained as having been blown in from neighbouring Neolithic settlements.

The palynological record of the first Neolithic in Poland agrees with the archaeological evidence. So, in Lake Gościąż in Central Poland, the first Neolithic disturbance phase begins around $5400 \mathrm{cal}$ B.C. and corresponds to the start of the Linearbandkeramik nearby (Ralska-Jasiewiczowa and van Geel 1992). In North-west Poland the first phase of human activity in pollen diagrams starts around $4100 \mathrm{cal}$ B.C. (e.g. Lake Skrzetuszewskie, Tobolski 1990; Wolin island, Latałowa 1992) and is connected with the Neolithic, which begins here at the same time as in the adjoining north-eastern Germany.

Further to the south, the situation is similar: in Czechia the pollen evidence of earliest farming corresponds to the beginning of the Linearbandkeramik culture around 5500 cal B.c. (e.g. Vracov, Rybníčková and Rybníček 1972, 1996; Svobodová 1997) and there is no discussion of 'Mesolithic agriculture'.

\section{North-west Europe}

There is almost no discussion of 'Mesolithic agriculture' in the Low Countries. Single Cerealia-type pollen grains, which were sometimes recorded from pre-Neolithic times, e.g. from the Late-glacial in Zandvliet/Belgium (Munaut 1967), were not connected to agriculture. As in neighbouring Germany the earliest arable farming started with the Linearbandkeramik culture in the loess area and was also continued later during the Michelsberg culture on the adjoining soils where a clear loess cover was lacking. North of these Neolithic cultures for a long time Mesolithic conditions without farming prevailed.

Around $4700 \mathrm{cal}$ B.C. is the beginning of the Swifterbant culture which is restricted to the wetland areas in the Dutch delta region and starts in the pure Mesolithic (Louwe Kooijmans 1998; Raemaekers 1999). The Neolithic in this area only begins with Swifterbant 3 around 4300 cal B.c. This has been best investigated at the type locality Swifterbant; other sites are the donken, in particular the Hazendonk. The pottery is Neolithic and from 4200/4100 cal B.c. cereal grains are regularly recorded, mainly of emmer and naked barley (Bakels 1981; van Zeist and Palfenier-Vegter 1983). These wetland sites, however, still have an important Mesolithic element, in that more bones from wild than from domestic animals were found there. Permanent occupation of Swifterbant is still under debate; significant arguments point to hunting camps used throughout the summer. Behind them permanent settlements must have existed on the dry ground where the fields were also situated. 
Obviously temporary outer stations in wetland areas must have been common across a larger region in those times. An important site of that kind is represented by the settlement Hüde at Lake Dümmer in Lower Saxony, which also starts around 4200/4100 cal B.C. (Kampffmeyer 1983). The pottery, influenced by the Rössen culture, as well as the flint material is Neolithic, while the settlement as a whole is based on hunting and fishing. However, bones of domestic animals and cereal grains were present in all settlement layers. With one exception the Cerealia-type pollen grains in the numerous pollen diagrams were always found above the elm decline, that is to say after about 4000 cal B.C. (Schütrumpf 1988). It is also assumed for Hüde that this wetland site was used only temporarily while a permanent settlement with fields was situated in the dry hinterland.

In the British Isles, as in mainland Europe, there are records of Cerealia-type pollen grains long before the archaeological and archaeobotanical evidence for the beginning of the Neolithic. Here also local Mesolithic crop cultivation has been discussed by several authors. Edwards and Hirons (1984) compiled five pollen diagrams from different authors from Ireland and three from Great Britain, where Cerealia-type pollen grains appeared before the elm decline. This event, dating to around 4000 cal B.C., is also taken as the time horizon for the archaeological start of the Neolithic in Britain, while the first dates from Ireland are some centuries earlier. The earliest Cerealia-type pollen grains were recorded at $5845 \pm 100$ B.P. (4700 cal B.c.) and the authors concluded probable arable agriculture in a Proto-Neolithic phase. Later Edwards (1988, 1989) produced maps with 22 sites from the British Isles, where pollen grains from the pre-elm decline period were found. In these papers the author points to possible arable farming with, however, the reservation "if the cereal-type grains really do derive from Cerealia", thus acknowledging the identification difficulties.

The proof of such early agriculture in the British Isles was contested by O'Connell (1987). He checked 20 pre-Neolithic large grass pollen grains from the Irish pollen profiles Connemara National Park and Namackanbeg by employing all possible techniques. He found that according to the applied criteria 16 of these must come from wild Poaceae although their sizes were up to $55 \mu \mathrm{m}$. The remaining four belonged to the general Cerealia-type or even the Triticum-type (most of the grains were checked and confirmed by Küster). To the latter type belonged the oldest grain of this series, dating to 7570 B.P. (6442 cal B.C.). In another pollen diagram from the early Late-glacial in Limerick, Western Ireland, O'Connell et al. (1999) even recorded a surprising $8 \%$ of Secale pollen besides a few grains of the Triticum-type. This large percentage forced him to postulate the occurrence of a wild $\mathrm{Se}$ cale species in the Irish Late-glacial. This was supported by other finds of late-glacial Secale pollen in Ireland, even from as recently as the early Holocene. In the meantime Tweddle et al. (2005), using a large and well-dated dataset from Holderness, England, have shown that there also, the early records of Cerealia-type pollen grains probably derive from wild grasses (see preceding section). According to present knowledge in the British Isles pre-Neolithic crop cultivation also cannot be proved.

\section{Southern Germany}

It was G. Kossack and H. Schmeidl who started the whole discussion in their provoking paper of 1975: Vorneolithischer Getreidebau im bayerischen Alpenvorland. Obviously they were strongly influenced by V. Milojčić, who proposed in 1960a 'pre-ceramic Neolithic' on the Balkan peninsula, which idea was however abandoned later. For some time the idea of pre-Neolithic cereal cultivation in South Germany had been derided as 'Kossackienne', but again and again since then single pollen finds of the Cerealia-type have been taken as an indication of cereal cultivation. In recent years this theory has been taken up in several papers, mainly by archaeologists.

As was described earlier, the occurrence of Cerealia-type pollen grains in Holocene as well as Pleistocene diagrams is not unusual, therefore only those sites often referred to in connection with the earliest arable farming are mentioned here.

First of all we have to consider the dates from the initial paper of Kossack and Schmeidl itself. The two key sites Allmannshausen and Bachhausen are situated at Lake Starnberg in Upper Bavaria. The pollen diagrams were prepared in 1960 by H. Baumann, under the supervision of J.L. Lutz; their data were published later by Kossack and Schmeidl (1975). Some Cerealia are even called Triticum-type although it is stated that phase contrast was not employed (and reliable keys were not yet available). The pollen diagrams are difficult to date because there is no absolute time control. No rationale is given for the zonation of the pollen diagrams. As is shown by the modern pollen diagrams from upper Bavaria (Küster 1988, 1995), dating without ${ }^{14} \mathrm{C}$ dates is very difficult in this region. The first single Cerealia-type pollen grains in the diagrams from Allmannshausen and Bachhausen may have appeared before 5000 cal B.C., but probably after $5500 \mathrm{cal}$ B.C. This is not certain, however. Nevertheless this is already in the range of the Linearbandkeramik culture, settlements of which are known from $50 \mathrm{~km}$ north-east of these sites (see below).

Modern pollen diagrams from Upper Bavaria, analysed by Küster $(1988,1995)$ regularly show single pollen grains of the Cerealia- or Triticum-type in the Atlantic period. In three diagrams from around the Auerberg they start at about 5300 cal B.C. and in the Pilsensee diagram, from $50 \mathrm{~km}$ further north-west, at 5200 cal B.C. So far as they really indicate 
early agriculture, this might not necessarily be pre-Neolithic because it is within the Linearbandkeramik period. For a long time this culture had been known only from Lower Bavaria, but recent discoveries indicate Linearbandkeramik settlements in Upper Bavaria also. This culture occupied in particular the Riss-Lech-Plate southwards up to Landsberg (Wischenbarth 1995; Neumair 1999), which are only 25 and $40 \mathrm{~km}$ respectively from the pollen sites mentioned above. In the southwest Linearbandkeramik settlements are known from the Hegau in Kreis Konstanz (Stika 1991). New finds of Bandkeramik settlements in this region are still possible; on the other hand pollen transport across these relatively small distances also has to be taken into account. Given the high pollen counts in these diagrams (generally from 1000 to more than 2000 grains per sample) even very rare pollen types such as Cerealia could be detected.

An important La-Hoguette site has been excavated at Stuttgart-Bad Cannstatt and for this culture the question of possible agriculture is not yet definitely resolved. There a La-Hoguette habitation layer, confirmed by a ${ }^{14} \mathrm{C}$ date of $6353 \pm 45$ B.P. or $5460-5290 \mathrm{cal}$ B.C. is intercalated between travertine deposits (Meurers-Balke and Kalis 2001). The authors present a pollen diagram and several single pollen spectra with single pollen grains of Triticum- as well as Hordeum-type from the layer itself. While the Hordeumtype grains are regarded to come from the natural vegetation, the single Triticum-type grains that occur in two soil samples are interpreted as proof of cereal cultivation (p. 644). However, the archaeological evidence from this site (Strien and Tillmann 2001) as well as the reconstruction of the environment by Kalis et al. (2001) shows a pure and only short-term Mesolithic settlement, surrounded by natural vegetation. Therefore an aeolian origin was not even discussed by the authors because they did not expect fields in the surroundings and the records were explained as deriving from wheat threshing in the settlement in the course of which a lot of pollen is generally released. There is, however, no suggestion as to where the ears might have come from. Notwithstanding the fact that this activity would produce much more cereal pollen (the authors themselves suggest at least $15 \%$ of a pollen spectrum based on their own Bandkeramik experience), threshing would indicate local cereal production even more than single Cerealia pollen blown in from more-or-less distant fields.

The pollen diagram from this site also shows single Triticum-type pollen, but below and above the settlement layer. According to the detailed description of their methods, phase contrast was not employed for the analyses, making a reliable identification of this type even more improbable. The clear conclusion is that these pollen grains from the pollen diagram as well as from the soil samples originate from wild grasses or other sources (see preceding section) and do not indicate any agriculture.
Also other palynologists who worked in this region, such as Rösch (1985) or Smettan (1986), reported single Cerealiatype pollen grains from pre-Linearbandkeramik times but attached no significance to these finds.

\section{Switzerland}

There are several papers from Switzerland and some other Alpine regions where the primary authors or later secondary authors claim very early pre-Neolithic agriculture. A summary discussion for the Swiss Uplands has been published recently by Erny-Rodmann et al. (1997).

Very early Cerealia-type pollen records from the Wallis in southern Switzerland, published by Welten (1982), were often presented as proof of 'Mesolithic agriculture'. The most important site is Lac du Mont next to Sion at $640 \mathrm{~m}$ a.s.l. Single grains appear from (interpolated) 7700 B.P. or around 6500 cal B.C., while a continuous curve starts at around (interpolated) 6300 B.P. or $5300 \mathrm{cal}$ в.c. The latter is accompanied by the first appearance of, or a considerable increase in several anthropogenic indicators that clearly indicate arable farming.

Unfortunately the ${ }^{14} \mathrm{C}$ dates of this diagram are not reliable. There is an inversion of the most important data for 7890 в.P. and 7630 в.P. and Welten himself proposed this early agriculture only with the reservation that the ${ }^{14} \mathrm{C}$ data he presented were correct. With respect to the lime content of the deposits, this inversion probably has to be attributed to the hard-water effect, which had not been taken into account here and may lead to an age reduction of up to 1000 years. The start of agriculture as shown in this diagram is probably much later than the age of (interpolated) 6300 B.P. or 5300 cal B.C. originally assumed by Welten. In the meantime a Neolithic settlement was discovered in the town of Sion, Place de la planta, which shifts the onset of the Neolithic in Wallis to around $5000 \mathrm{cal}$ B.C. and probably corresponds to the pollen evidence (Gallay 1986).

There are several other diagrams with single Cerealia pollen grains from before Neolithic times. An example is in the pollen diagram from Soppensee, where the first Cerealia grain has already appeared before $8110 \pm 100$ B.P., that is about $7100 \mathrm{cal}$ B.C.; another 2 are recorded from around 7700 B.P. or about $6500 \mathrm{cal}$ B.C., later there are more (Lotter 1999). Also from the Nussbaumer See single pollen grains of the Cerealia-type were recorded very early (before 6100 cal B.C., Rösch 1983). In both cases the authors did not infer farming from these finds.

Haas (1996) explicitly presented the pollen diagram from Wallisellen-Langachermoos adjacent to Zürich as evidence of very early agriculture. He describes three cultural phases with agriculture. While the dating is very good, the pollen record of the human impact is weak. The first cultural phase at $6400 \mathrm{cal}$ B.C. is characterised by two grains of Triticum- 
type and two grains of Rumex acetosa-type, the second one around $5800 \mathrm{cal}$ B.c. by one Triticum-type together with one grain of Plantago lanceolata and Rumex acetosa-type; both phases are not supported by archaeology. The third cultural phase between 5200 and 4900 cal B.C. has some more Cerealia and other anthropogenic indicators and is correlated with the Linearbandkeramik and the subsequent Großgartach group.

Haas is fully aware of the difficulties in reliable identification of Cerealia pollen, when he, in agreement with Beug, notes that species like Bromus, Agropyron and to a less extent Elymus might show very similar features to Triticum and he also considers long-distance transport of pollen. His confidence in agriculture around the site is based on a seed find of Linum usitatissimum in the lake deposits at the depth of his cultural phase 1 . If the identification were certain, this would be a good argument in favour of very early agriculture. This record, however, has to be questioned because of the size of the seed. With a length of $3.1 \mathrm{~mm}$ it is within the range not only of Neolithic Linum usitatissimum, but also of some wild Linum species. A list of seed measurements of some modern species has already been given by Jacomet et al. (1989). More extensive ones have been carried out by the author and gave lengths as shown in Table 1 .

This shows that the seed from WallisellenLangachermoos is within the size range of the first four wild Linum species. All these occur on dry meadows or pastures and in dry forests. Nowadays they are no longer very common in and around Switzerland; L. perenne is even absent from Switzerland, but according to Hess et al. (1970) was present in the Thurgau, northeast of the site in the 19th century.

With regard to the size distribution of linseeds, the seed in question may well have come from one of the wild species, transported into the lake by a stream, by wind or birds. It should be mentioned that pollen grains of Linum usitatissimum-type (which includes also its ancestor $L$. angustifolium) can be identified as such with certainty, but they have not been found here.

On the basis of the publication on WallisellenLangachermoos, complemented by a neighbouring diagram from Zürich-Mozartstraße and referring to other early
Cerealia records in the Alps, Erny-Rodmann et al. (1997) have tried to make the existence of a 'Mesolithic agriculture' certain. According to them "erfolgte die Neolithisierung des zentralen Schweizer Mittellandes als langdauernde Folge mehrphasiger und wohl auch diskontinuierlicher Akkulturationsprozesse der lokalen spätmesolithischen Bevölkerung." (The Neolithisation of the central Swiss Plateau took place as a long-lasting sequence of multiphase and probably also discontinuous acculturation processes undergone by the local late Mesolithic population). In the pollen diagram ZürichMozartstrasse pollen grains of Cerealia-type (not differentiated further) were recorded regularly between 7460 and 7060 B.P. or 6300 and $5950 \mathrm{cal}$ в.C., later a single one occurred around $5400 \mathrm{cal}$ B.C. and then from (interpolated) $5300 \mathrm{cal}$ B.C. the number increases again. The anthropogenic indicators to which the authors repeatedly refer are, however, very weak and do not support the proposed cultural phases. The important curve of Poaceae is completely lacking in the diagram. Again this pollen diagram does not at all prove the existence of 'Mesolithic agriculture'.

Another two pollen profiles from the Swiss Plateau were investigated by Beckmann (2004) and van Leeuwen (in Beckmann 2004): Wauwilermoos, where there are numerous Meso- and Neolithic sites, and Bibersee. Both yielded one Cerealia-type pollen grain from around $6800 \mathrm{cal}$ B.C. and 6300 cal B.C. respectively, associated with small numbers of other anthropogenic indicators which were tentatively regarded as disturbances. Beckmann, however, does not insist on 'Mesolithic agriculture'. Wegmüller (1976) had already recorded single Cerealia pollen grains in his diagram Wauwilermoos which predated high quantities in the Neolithic occupation layer Egolzwil 5 around 4400 cal B.c.

A comparison of the various finds of early Cerealia pollen, including those not discussed above, shows that they come from quite different time phases between $7100 \mathrm{cal}$ B.C. and the start of the Neolithic. Even between neighbouring profiles as at lake Zürich the data do not agree. Synchronous phases of agriculture cannot be recognised on the Swiss Plateau. If the pollen records are accepted as proof of arable farming one has to imagine a perpetual flaring up and disappearance of limited agriculture as has been suggested by Erny-Rodmann et al. (1997). This must have had severe consequences for
Table 1 Length of seeds of wild Linum species from Central Europe

*according to Heer (1872)

\begin{tabular}{llll}
\hline Species & Length $(\mathrm{mm})$ & Average $(\mathrm{mm})$ & No of measurements \\
\hline Linum austriacum $\mathrm{L}$. & $2.9-3.6$ & 3.28 & 50 \\
Linum perenne $\mathrm{L}$. & $3.0-3.6$ & 3.42 & 50 \\
Linum viscosum L. & $3.1-3.6$ & 3.37 & 40 \\
Linum angustifolium Huds. & & ca. $3 \mathrm{~mm}^{*}$ & \\
Linum tenuifolium L. & $1.9-2.3$ & 2.12 & 50 \\
Linum alpinum Jacq. & & & \\
ssp. montanum (Schleich.) Koch & $4.2-5.1$ & 4.56 & 35 \\
ssp. leonii F. Schultz & $3.7-4.8$ & 4.19 & 20 \\
\hline
\end{tabular}


the whole economy, in particular for permanent habitation, where similar changes must have occurred. In contrast to this Nielsen (2003, p. 290) concludes from the same data that they prove agriculture and clearances occurring throughout the whole late Mesolithic (i.e. from 6700 to 5500 cal B.C.).

Another feature, as yet not discussed by the various authors, has to be considered here. Almost all early pollen grains from Switzerland have been found in lake deposits. It is exactly here that Glyceria species must be expected and their pollen partially belongs to the Cerealia-type.

In summary, with regard both to the uncertainties in identifying the Cerealia-type pollen grains and to the unknown origin of the scarce grains, and also because of their accidental temporal occurrence, the existence of 'Mesolithic agriculture' cannot be supported for Switzerland either. This is corroborated by insufficient connection with other anthropogenic indicators as well as the archaeological and archaeobotanical (macrofossil) evidence.

\section{Central Alps}

In the Central Alpine region 'Mesolithic agriculture' has been postulated from several pollen diagrams. On the Natzer Plateau near Brixen in Southern Tyrol Seiwald (1980) found a first pollen grain of 'Cerealia' at $9135 \pm 90$ B.P. (around 8400 cal B.C.), i.e. in the Preboreal, with another two in the Boreal. The author supposed they were polyploid wild grasses; even more probable is the assumption that they were Glyceria, as they occur at the change from the limnic to the telmatic stage, which is the optimum for the Glyceria species. In the secondary literature, however, these finds are taken as indicating cereal cultivation (Erny-Rodmann et al. 1997, p. 30; Gehlen and Schön 2003, p. 269). The accompanying anthropogenic indicators do not support this interpretation of these early finds: the Rumex curve, which is here strong from the Late-glacial, has already decreased considerably at this point. Plantago lanceolata also occurs in the Late-glacial but appears again only some time after the first Cerealia-type pollen grain.

Other very early records of 'Cerealia' are registered in the pollen diagrams Kirchbichl/Inn (512 m a.s.l.) and Katzenloch/north of the river Inn (1200 m a.s.l.; Wahlmüller 1985a, b). In the first of these a very early 'Cerealia' pollen grain was found at $9070 \pm 130$ B.P. (around $8250 \mathrm{cal}$ B.C.) followed between (interpolated) $7600 \mathrm{cal}$ в.C. and $8100 \pm 120$ B.P. (around 7050 cal B.C.) by a series of single grains succeeded by a longer interruption. In this gap, between $7470 \pm 120$ в.P. (around $6300 \mathrm{cal}$ B.C.) and $7100 \pm 180$ B.P. (around $6000 \mathrm{cal}$ B.C.) there is a series of 'Cerealia' grains in the diagram from Katzenloch, $80 \mathrm{~km}$ distant, following a single grain that had already appeared at (interpolated) $7550 \mathrm{cal}$ B.C. According to these data there should have been at Kirchbichl a short agricultural episode in the Preboreal, followed by a longer farming phase in the Boreal, which, after another interruption, was continued at Katzenloch in the early Atlantic until another pause set in. While the author herself only speaks of possible arable farming in these periods, this assumption was taken up in the secondary literature (e.g. Gehlen and Schön 2003, p. 267) as a precise statement "die ältesten Hinweise auf frühe Getreidenutzung im circumalpinen Gebiet" (the oldest hints of the early use of cereals in the circumalpine region). They mention an age of $7000 \mathrm{cal}$ B.C. which, however, is only the date of the end of the early 'Cerealia' finds that according to the original dates had already started much earlier (see above). Consequently, according to these authors, there would have been cereal cultivation in the Alps at least in the Boreal, although this is supported neither by archaeobotanical macro-remains nor by archaeological finds.

As early as 1964 Beug published the finding of a single pollen grain of the Triticum-type from the late Boreal at Lake Ledro in the southern Alps. This was soon included in the discussion of early arable farming, although the author himself - without doubt the most experienced pollen morphologist in Europe - considers it to come from a polyploid wild grass. In the secondary literature it is generally taken as cereal.

\section{France}

In France there is also continuous discussion about possible 'Mesolithic agriculture'. In order to verify this assumption a special program has been organised recently by H. Richard, resulting in a compilation called 'Néolithisation précoce. Premières traces d'anthropisation du couvert végétal à partir des données polliniques“ (Richard 2004, ed.).

Most of the 16 papers show pollen diagrams where the first Cerealia type pollen grains occur in early or middle Neolithic times. However there are five papers which already show single Cerealia-type pollen grains in (late) Mesolithic times. Generally these pollen grains are called 'Cerealia' without the suffix '-type'. Obviously phase contrast was not employed in the analyses as there is no differentiation into genus-types.

A key paper is that of Richard and Ruffaldi (2004), where several sites from the Jura and the Plateau Lorraine in eastern France were compiled. They conclude "The oldest traces attested to date appear very discretely by places as of 6000 cal B.C., and are obvious from 5500-5300. In the majority of the studied areas these pollinic traces seem to precede by a few centuries the archaeological indices known marking the beginning of the oldest Neolithic on a regional level". The pollen diagrams presented in this paper are very reduced and show only small time slices around the Mesolithic/Neolithic boundary. Most diagrams show single 'Cerealia-type' pollen grains in the (late) Mesolithic. However, if one looks at the complete diagrams in the original publications, single 
Cereal-type pollen grains can also be observed much earlier, e.g. in the diagram Joppécourt in the early Atlantic and in the diagram Francaltroff (both from Ruffaldi 1999) already in the middle Boreal. While these older 'Cerealia' were obviously not accepted as such by the authors, the younger ones were. In putting the records together, all pre-Neolithic $\mathrm{Ce}$ real grains here may well derive from wild grasses or other sources.

Leroyer (2004) presents pollen diagrams from floodplains in the Paris Basin. Three out of ten diagrams, drawn here in a very reduced form (only Cerealia, Plantago lanceolata and ruderals are given), show single Cerealia-type pollen grains before 5500 cal B.C. There is one grain in 'Marivel' from Sèvres (without ${ }^{14} \mathrm{C}$ dates), a few in 'La Bachère' from Chatenay-sur-Seine, starting around 6600 cal B.C. and depending on one ${ }^{14} \mathrm{C}$ date, and some more in 'La Boucle de Jablines' at Annet-sur-Marne. However, the latter diagram (an excerpt only) does not correspond with the original diagram (Leroyer 1997) where single Cerealia grains are noted only around 5120 cal B.C. and match very well the early Neolithic V.S.G. (La Villeneuve-Saint-Germain) culture in the region. With respect to early human impact in this region the author points in particular to some ruderals in the diagrams. However, as her pollen sites are situated in the floodplain areas, one has always to bear in mind that these are the natural homes of most of our ruderals from where they later migrated into the cultural landscapes. The author herself is sceptical about the interpretation of her Cerealia finds and writes "The evidence of the earliest introduction of cereal cultivation, on the other hand, is problematic because it is not at all corroborated by archaeological research".

Also Visset et al. (2004) present nine pollen diagrams relevant to this problem from sites along the lower Loire. Most of them show the first Cerealia in Neolithic layers, but three have records of single grains from considerably earlier. The pollen diagram from Montjean-sur-Loire looks very strange, with Cerealia-type pollen, accompanied by three pollen grains of Fagopyrum and one of Juglans, occurring around $7470 \pm 60$ B.P. (about 6300 cal B.C.). In view of the combination with the latter two species in particular, which would be expected to appear much later, a thorough reinvestigation of the site is highly desirable.

The detailed pollen diagram Marais du Grand-Chaumet (Indre) of Gauthier (2004) shows four pollen grains of Cerealia around $6990 \pm 50$ B.P., that is about 5900 cal B.C., followed by a wide gap. This discontinuous occurrence is interpreted as "proof of a succession of tests and abandonments of husbandries in this area during nearly one millennium". There are, however, no archaeological sites from this period known in the region. Other anthropogenic indicators, such as Plantago lanceolata, Rumex and Chenopodiaceae are mentioned to support the assumption of agriculture. These are, however, much more frequent in the earliest Atlantic, and in the Boreal and Preboreal periods, when farming was unlikely. Even P. lanceolata had already appeared in the Preboreal. So here again the early records of Cerealia should not be taken as proof of arable farming.

There are also other pollen diagrams from France with early single Cerealia-type pollen grains that are sometimes mentioned in connection with pre-Neolithic agriculture, e.g. that of Jalut 1995, but these do not show agriculture for certain. An example is Étang du Méjean in Hérault where Puertas (1999) investigated lagoon deposits with Cerealiatype pollen grains from 6200 cal B.C., however not dated precisely. Here one has to take into account the specific disturbances of littoral grasses with large pollen. How misleading such reports can be is shown for instance in the much-consulted atlas Huntley and Birks (1983). On p. 472 and 473 the oldest records of Cerealia-type in Europe (up to $4 \%$ !) are indicated for southern France as 11000 B.P. (10850 cal B.C.) and 10000 B.P. (9550 cal B.C.), taken from the pollen diagram Beauchamp-Panieres close to Saint Remy (Triat-Laval 1978). This is the Younger Dryas period and according to Triat-Laval (1978) steppic conditions then prevailed. The general comment of the authors of the atlas states, however (p. 469), "all occurrences of Cerealia-type pollen are regarded as indicative of local cereal cultivation unless there are strong reasons for doubting such an interpretation".

To sum up, the evidence for France shows quite a few pollen diagrams with single pre-Neolithic pollen grains of Cerealia-type, going back to the Preboreal and even Lateglacial periods. In particular in floodplain areas they are often accompanied by ruderal species, which also go back until late-glacial times. These are strong arguments that the Cerealia-type pollen comes from natural wild grass communities, if not from other sources (see above). The deciding point, however, is the total lack of crop remains from cultivated plants in pre-Neolithic times and the absence of clear connections between the pollen sites and archaeological sites. Some of the old Cerealia-type pollen finds may well have come from real early Neolithic settlements, the pattern of which is not yet sufficiently known.

\section{Conclusions}

The main intention of this contribution is to show that single pollen grains of Cerealia-type in pre-Neolithic parts of pollen diagrams have to be considered very carefully. There are various sources from where pollen of this type may come. True single cereal pollen grains may have their origin in contamination or long-distance transport, but these are probably very rare. The crucial point is the separation of cereal pollen from large wild grass pollen. Pollen morphology shows that 
in size as well as in the pores and the fine structure of the pollen wall there is some overlapping between wild grasses and cereals. This was confirmed by the application of the available keys to the identification of large pollen grains that are doubtless of non-cereal origin.

A thorough check of the literature on Mesolithic agriculture shows a rather confusing situation. In most pollen diagrams there is no information about the exact size of the grains and whether they were identified by size alone or also by the application of other criteria. Often merely Cerealia or Cerealia-type is recorded. The publications show that in many cases the original authors were fully aware of the difficulties with respect to reliable identification of single Cerealia pollen grains. Also their evaluation of the data is careful and includes other possibilities than local cereal cultivation, while other authors are very rigorous in making any assumption of early arable farming. However, many secondary authors writing about Mesolithic agriculture, sometimes archaeologists unfamiliar with the difficulties of pollen morphology, neglect the reservations of the palynologists and take their data as indicating cereals, often stripping off the suffix '-type'. This is the way the discussion was started by Kossack and Schmeidl (1975). Also some data banks are used in the way that real banks use money laundering, in that uncertain data are put in uncritically and clean ones come out and are used to gain new insights. This latter problem, however, is not restricted to our subject.

With regard to the increase in the finding of single preNeolithic Cerealia-type pollen grains, another factor is the increased pollen sum of modern pollen counts (often more than $1000 \mathrm{AP}$ ). As described above this increases the chance of detecting rare species and aberrant wild grass pollen including those outside the range of Beug 's (2004) or Andersen's (1979) measurements, thus leading to an overemphasis on irrelevant grains.

Ruderals and other secondary anthropogenic indicators (Behre 1981) are very important for the recognition of culture phases in pollen diagrams. However, many of these species are native and occur in small open biotopes, whether these are natural or already created by the activity of man under true Mesolithic conditions. Only later did these apophytes become anthropogenic indicators like the introduced anthropochores, when they occupied the man-made clearings or eutrophied stands. Therefore the presence of small amounts of this pollen has also to be considered carefully if taken as support for agriculture.

Another important point is the question of the contemporaneity of the phases of supposed 'Mesolithic agriculture'. In all regions considered here the occurrence of the single 'Cerealia' is spread across all pre-Neolithic periods and there are no synchronous phases if different pollen diagrams are compared. In several diagrams the authors point to the occur- rence of 'Cerealia' in late Mesolithic times only but ignore this pollen type in Boreal, Preboreal or even late-glacial parts in the same diagrams. Scientifically it is, however, implausible to interpret some of these 'Cerealia' as indicators for agriculture while others that appear as too early or too high in the mountains are not accepted as such.

Other authors, e.g. Gehlen and Schön (2003), also use some very early records of Cerealia-type pollen and take them as the oldest hints of cereal production in the circumalpine region. According to these authors, and through the use of the diagrams of Wahlmüller (1985a, b) from Tyrol in the Central Alps, farming already took place in the Boreal or on the Swiss Plateau slightly later at the Boreal/Early Atlantic transition (Erny-Rodmann et al. 1997).

According to these authors, there must have been many phases of small scale 'Mesolithic agriculture' which started and disappeared here and there but were not synchronous. Because crops cannot be produced without protecting the fields, permanent settlements are a precondition. Consequently the start of permanent settlements together with the introduction of cultivated plants must have taken place several times and between these phases the advantages of this new (Neolithic) economy including the know-how of agriculture were abandoned and for several generations the former farmers went back to being again hunters, fishers and gatherers. On the other hand Nielsen (2003) suggested continuous farming on the Swiss Plateau for the whole late Mesolithic, i.e. from 6700 cal B.c. and for him the neolithisation began at the start of this period. Both theories depend solely on the assessment of some single pollen grains of the Cerealia-type. If these were to be accepted as wild grass pollen, their accidental occurrence across space and time would not need any explanation.

For the different regions of Europe north of the Alps covered in this investigation there are great similarities with respect to the identification of the Cerealia-type pollen by the various authors as well as for the more or less accidental occurrence of these grains in time and space. The most important agreement, however, is the lack of archaeological context and in particular the lack of hard archaeobotanical evidence in the form of well dated carbonised cereal grains from pre-Neolithic times. Across this large part of Europe hundreds, or even more than a thousand Mesolithic sites have been excavated, but up to now there has not been a single find of a cereal grain. In this paper it is also shown that the Mesolithic Linum seed found by Haas (1996) in lake deposits at Wallisellen-Langachermoos (but without an archaeological context), regarded by several authors as the long expected proof of Mesolithic agriculture, may well have come from a wild Linum species.

In large parts of Europe, agriculture started with the Neolithic Linearbandkeramik culture. The oldest LBK phase in Austria, Czechia and Central Germany began around 5500 


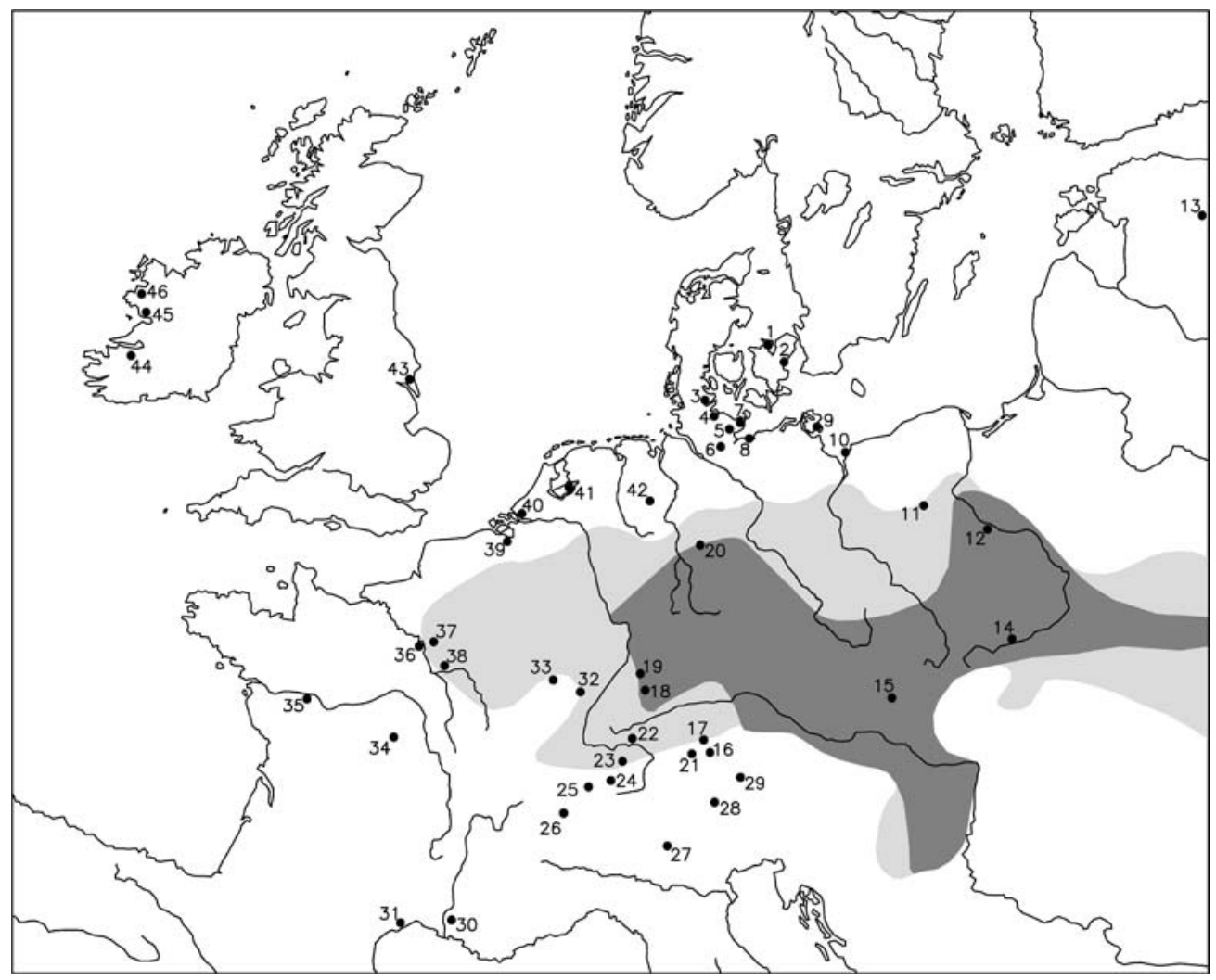

Fig. 1 Sites referred to in the text. Shading: Dark grey - distribution of the earliest phase of the Linearbandkeramik from around 5500 cal B.C. Light grey - its expansion after $5300 \mathrm{cal}$ B.C. (after Lüning 2000, slightly modified). 1 Trundholm, 2 Ordrup Mose, 3 Satrupholmer Moor, 4 Wellsee, 5 Belauer See and Plöner See, 6 Schlamersdorf and Bad Oldesloe, 7 Rosenhof, Wangels and Siggeneben-Süd, 8 WismarBay, 9 Lietzow-Buddelin, 10 Wolin, 11 L. Skrzetuszewskie, 12 L. Gościąż, 13 Akali, 14 Pleszów, 15 Vracov, 16 Allmannshausen, Bachmannshausen and Pilsensee, 17 Landsberg, 18 Stuttgart-Bad Cannstatt,
19 Sersheim, 20 Luttersee, 21 Auerberg, 22 Hegau, 23 Nussbaumer See, 24 Zürich-Mozartstrasse and Wallisellen-Langachermoos, 25 Wauwilermoos, Bibersee and Soppensee, 26 Lac du Mont and Sion, 27 Ledrosee, 28 Natzer Plateau, 29 Kirchbichl and Katzenloch, 30 Beauchamps-Panieres, 31 Étang du Méjean, 32 Francaltroff, 33 Joppécourt, 34 Marais du Grand-Chaumet, 35 Montjean-sur-Loire, 36 Sevres 'Marival', 37 La Bouche de Jablines, 38 La Bachère, 39 Zandvliet, 40 Hazendonk, 41 Swifterbant, 42 Hüde, 43 Holderness, 44 Tory Hill, 45 Namackanbeg, 46 Connemara National Park cal B.C.; during the second phase of this culture 5300-5000 cal B.C. huge additional areas from the Paris Basin to Southern Poland were occupied (Lüning 2000; Kreuz in press). From this culture many excavations revealed large amounts of charred remains of crop plants. Already in 1980 the archaeobotanical compilation of Willerding was based on more than 100 investigated sites; since then the number has further increased (see e.g. Knörzer 1988; Kreuz 1990, van Zeist et al. 1991; Kreuz et al. 2005). Good pollen analytical documentation of this culture is rare, however, mainly due to the lack of suitable deposits in the well-drained loess areas where these early farmers lived. Very clear reflections of LBK economy are registered in the pollen diagrams from Luttersee, south of the Harz mountains (Beug 1986), Sersheim in Württemberg (Smettan 1986) or Pleszów near Kraków (Wasylikowa et al. 1985); there Cerealia pollen is well represented with several types.

Outside the area of the LBK and later also the Rössen culture, the Mesolithic continued for more than one millen- nium. In the regional sections it is shown that in Northern Germany/Denmark/Scandinavia, The Netherlands and Britain no arable farming can be traced until around $4100 / 4000$ B.C., when also according to the material culture the Neolithic started in these areas. Archaeobotanical records of crop plants are completely lacking and the assumption of 'Mesolithic agriculture' is merely based on the few finds of Cerealia-type pollen mentioned above.

As long as there are no certain, reliably dated finds of macroscopic cereal grains from a site with a Mesolithic material culture, there is no evidence of Mesolithic agriculture in the area in question. Large wild grass (not necessarily polyploid) pollen grains are responsible for most of the Cerealia-type pollen records while other sources like long-distance transport and possible contamination probably contribute only very little to these finds.

Pollen analysis remains a very important tool for the reconstruction of former human impact and especially for the 
history of agriculture. However, this discipline has also always to be applied with the necessary care.

Acknowledgements This contribution is dedicated to H.-J. Beug on the occasion of his $75^{\text {th }}$ birthday with cordial thanks for good cooperation over several decades.

In the preparation of this article I had long discussions with several colleagues; of these I wish to thank F. Bittmann, W. Dörfler, S. Jacomet, A. Kreuz, L. Louwe Kooijmans and J. Wiethold for valuable comments on this subject. Thanks are also due to M. Spohr, who drew the Figure 1.

\section{References}

Andersen ST (1979) Identification of wild grass and cereal pollen. Danmarks Geologiske Undersøgelse, Årbog 1978:69_ 92

Averdieck F-R (1974) Zur Vegetations-, Siedlungs- und Seegeschichte. In: Hinz H, Nellissen H-E, Helmuth H, Prange W, Averdieck F-R (eds) Bosau I. Offa-Bücher 31. Wachholtz, Neumünster, pp 150 169

Averdieck F-R (1978) Palynologischer Beitrag zur Entwicklungsgeschichte des Großen Plöner Sees und der Vegetation seiner Umgebung. Archiv für Hydrobiologie 83:1-46

Averdieck F-R (1990) Untersuchungen zur Geobotanik bei Bad Oldesloe. Meyniana 42:115-122

Bakels C (1981) Neolithic Plant Remains from the Hazendonk, Province of Zuid-Holland, The Netherlands. Zeitschrift für Archäologie 15:141-148

Beckmann M (2004) Pollenanalytische Untersuchung der Zeit der Jäger und Sammler und der ersten Bauern an zwei Lokalitäten des Zentralen Schweizer Mittellandes. Diss Bot 390. Cramer, Berlin, Stuttgart

Behre K-E (1962) Pollen- und diatomeenanalytische Untersuchungen an letztinterglazialen Kieselgurlagern der Lüneburger Heide. Flora 152:325-370

Behre K-E (1981) The interpretation of anthropogenic indicators in pollen diagrams. Pollen et Spores 23:225-245

Behre K-E (ed) (1986) Anthropogenic Indicators in Pollen Diagrams. Balkema, Rotterdam, Boston

Behre K-E, Lade U (1986) Eine Folge von Eem und 4 WeichselInterstadialen in Oerel/Niedersachsen und ihr Vegetationsablauf. Eiszeitalter und Gegenwart 36:11-36

Beug H-J (1961) Leitfaden der Pollenbestimmung, Lieferung 1. Fischer, Stuttgart

Beug H-J (1964) Untersuchungen zur spät- und postglazialen Vegetationsgeschichte im Gardaseegebiet unter besonderer Berücksichtigung der mediterranen Arten. Flora 154:401444

Beug H-J (1986) Vegetationsgeschichtliche Untersuchungen über das Frühe Neolithikum im Untereichsfeld, Landkreis Göttingen. In: Behre K-E (ed) Anthropogenic Indicators in Pollen Diagrams. Balkema, Rotterdam, pp 115-124

Beug H-J (2004) Leitfaden der Pollenbestimmung für Mitteleuropa und angrenzende Gebiete. Pfeil, München

Bittmann F (1992) The Kärlich Interglacial, Middle Rhine region, Germany: vegetation history and stratigraphic position. Veget Hist Archaeobot 1:243-258

Bjerck LGB (1988) Remodelling the Neolithic in Southern Norway: Another Attack on a Traditional Problem. Norwegian Archaeological Rev 21:21-32

Bortenschlager S (1965) Funde afrikanischer Pollen in den Alpen. Die Naturwissenschaften 52:663-664
Bottema S (1992) Cereal-type pollen in the Near East as indicators of wild or domestic crops. Préhistoire de l'agriculture: Nouvelles approches expérimentales et ethnographiques. Monographie du CRA no. 6, éd. CNRS

Drescher-Schneider R (1993) Funde nordafrikanischer Pollen in spätund postglazialen Sedimenten am Südrand der Alpen. Diss Bot 196. Cramer, Berlin, Stuttgart, pp 415-425

Edwards KJ (1988) The Hunter-Gatherer/Agricultural Transition and the Pollen Record in the British Isles. In: Birks HH, Birks HJB, Kaland PE, Moe D (eds) The cultural landscape-past, present and future. Cambridge University Press, Cambridge, pp 255266

Edwards KJ (1989) The cereal pollen record and early agriculture. BAR International Series 496:113-135

Edwards KJ, Hirons KR (1984) Cereal Pollen Grains in Pre-elm Decline Deposits: Implications for the Earliest Agriculture in Britain and Ireland. Journal of Archaeological Science 11:71-80

Endtmann E (2002) Das Herthamoor - ein palynostratigraphisches Leitprofil für das Holozän der Insel Rügen. Greifswalder Geographische Arbeiten 26:143-148

Endtmann E (2005) Erste Ergebnisse der neuen paläobotanischen Untersuchungen am mesolithischen Fundplatz von Lietzow-Buddelin auf Rügen. Jahrbuch 2004, Bodendenkmalpflege in MecklenburgVorpommern 52:197-209

Erny-Rodmann C, Gross-Klee E, Haas JN, Jacomet S, Zoller H (1997) Früher human impact und Ackerbau im Übergangsbreich Spätmesolithikum-Frühneolithikum im schweizerischen Mittelland. Jahrbuch der Schweizerischen Gesellschaft für Ur- und Frühgeschichte 80:27-56

Firbas F (1937) Der pollenanalytische Nachweis des Getreidebaus. Zeitschrift für Botanik 31:447-478

Gallay A (1986) Die Grundlagen der prähistorischen Chronologie im Wallis. Antiqua 15:44-61

Gauthier E (2004) Un exemple d'indices polliniques d'anthropisation anciens dans le Berry: le cas du Grand-Chaumet (Saint-Aoustrille, Indre). In: Richard H (ed) Néolithisation précoce. Premières traces d'anthropisation du couvert végétal à partir des données polliniques. Besançon: Presses Universitaires de Franche-Comté (Annales Littéraires de l'Université de Franche-Comté; vol. 777; série "Environnement, sociétés et archéologique"). 7, 81-88

Gehlen B, Schön W (2003) Das Spätmesolithikum und das initiale Neolithikum in Griechenland - Implikationen für die Neolithisierung der alpinen und circumalpinen Gebiete. Archäologische Informationen 26:255-273

Grohne U (1957) Die Bedeutung des Phasenkontrastverfahrens für die Pollenanalyse, dargelegt am Beispiel der Gramineenpollen vom Getreidetyp. Photographie und Forschung 7:237-248

Haas JN (1996) Pollen and plant macrofossil evidence of vegetation change at Wallisellen-Langachermoos (Switzerland) during the Mesolithic-Neolithic transition 8500 to 6500 years ago. Diss Bot 267. Cramer, Berlin, Stuttgart

Hartz S (1999). Frühbäuerliche Küstenbesiedlung im westlichen Teil der Oldenburger Grabenniederung (Wangels LA 505). Ein Vorbericht. Offa 54/55:19-41

Hartz S, Heinrich D, Lübke H (2000) Frühe Bauern an der Küste. Neue 14C-Daten und aktuelle Aspekte zum Neolithisierungsprozeß im norddeutschen Ostseeküstengebiet. Praehistorische Zeitschrift 75:129-152

Hartz S, Lübke H (2005)` Zur chronostratigraphischen Gliederung der Ertebölle-Kultur und frühesten Trichterbecherkultur in der südlichen Mecklenburger Bucht. Jahrbuch 2004, Bodendenkmalpflege in Mecklenburg-Vorpommern 52:119-143

Hartz S, Lübke H, Terberger T (in press) From fish and seal to sheep and cattle - new research into the process of neolithisation in northern Germany. In: Whittle A, Cummings V (eds) Going over: the Mesolithic-Neolithic transition in north-west Europe. London 
Hess HE, Landolt E, Hirzel R (1970) Flora der Schweiz, Vol. 2. Birkhäuser, Basel

Hoika J (1994) Zur Gliederung der frühneolithischen Trichterbecherkultur in Holstein. In: Hoika J, Meurers-Balke J (eds) Beiträge zur frühneolithischen Trichterbecherkultur im westlichen Ostseegebiet. Wachholtz, Neumünster, pp 85-131

Huntley B, Birks HJB (1983) An atlas of past and present pollen maps for Europe: 0-13000 years ago. Cambridge University Press, Cambridge

Iversen J (1949) The Influence of Prehistoric Man on Vegetation. Danmarks Geologiske Undersögelse, V. R.3, 6, Reitzel, Copenhagen, pp 5-25

Jacomet S, Brombacher C, Dick M (1989) Archäobotanik am Zürichsee. Zürcher Denkmalpflege, Monographien 7. Orell Füssli, Zürich

Jalut G (1995) Analyse pollinique de sédiments holocènes de l'étang de Capestang (Hérault), Temps et Espaces dans le Bassin de l'Aude du Néolithique à l'Age du Fer, resp. J. Guilaine. A.T.P., Grands Projets d'Archéologique Métropolitaine, pp 293-302

Kalis AJ, Meurers-Balke J (1988) Wirkungen neolithischer Wirtschaftsweisen in Pollendiagrammen. Archäologische Informationen 11:39-53

Kalis AJ, Meurers-Balke J (1998). Die "Landnam"-Modelle von Iversen und Troels-Smith zur Neolithisierung des westlichen Ostseegebietes - ein Versuch ihrer Aktualisierung. Praehistorische Zeitschrift 73:1-24

Kalis AJ, Meurers-Balke J, Borg K van der, Driesch A von den, Rähle W, Tegtmeier U, Thiemeyer H (2001) Der La-Hoguette-Fundhorizont in der Wilhelma von Stuttgart-Bad Cannstatt. Archäologische Berichte 14:649-672

Kampffmeyer U (1983) Der neolithische Siedlungsplatz Hüde I am Dümmer. Archäologische Mitteilungen aus Nordwestdeutschland, Beiheft 1:119-134

Knörzer K-H (1988) Untersuchungen der Früchte und Samen. In: Der bandkeramische Siedlungsplatz Langweiler 8. Rheinische Ausgrabungen 28:813-852

Köhler E, Lange E (1979) A contribution to distinguishing cereal from wild grass pollen grains by LM and SEM. Grana 18:133-140

Kolstrup E (1988) Late Atlantic and Early Subboreal Vegetational Development at Trundholm, Denmark. J Archaeol Sci 15:503-513

Kossack G, Schmeidl H (1975) Vorneolithischer Getreidebau im bayerischen Alpenvorland. Jahresbericht der Bayrischen Bodendenkmalpflege 15/16:7-23

Kreuz A (1990) Die ersten Bauern Mitteleuropas. Eine archäobotanische Untersuchung zu Umwelt und Landwirtschaft der ältesten Bandkeramik. Analecta Praehistorica Leidensia 13. Universiteit Leiden

Kreuz A (2006) Archaeobotanical considerations on the beginning of agriculture north of the Alps. In: Colledge S, Conolly J (eds) Agriculture in Southwest Asia and Europe; Archaeobotanical Perspectives in Neolithic Plant Economies. UCL Press, London (in press)

Kreuz A, Marinova E, Schäfer E, Wiethold J (2005) A comparison of early Neolithic crop and weed assemblages from the Linearbandkeramik and the Bulgarian Neolithic cultures: differences and similarities. Veget Hist Archaeobot 14:237-258

Küster H (1988) Vom Werden einer Kulturlandschaft. Verlag Chemie, Weinheim

Küster H (1995) Postglaziale Vegetationsgeschichte Südbayerns. Akademie-Verlag, Berlin

Lange E, Jeschke L, Knapp H (1986) Die Landschaftsgeschichte der Insel Rügen seit dem Spätglazial. Schriften zu Ur- und Frühgeschichte 38, 2 parts. Akademie-Verlag, Berlin

Latałowa M (1992) Man and vegetation in the pollen diagrams from Wolin island (NW Poland). Acta Palaeobotanica 32:123249
Leroyer C (1997) Homme, climat, végétation au Tardi- et Postglaciaire dans le Bassin parisien: apports de l'étude palynologique des fonds de vallée. Thèse de l'Université de Paris I Panthéon-Sorbonne, 2 vol

Leroyer C (2004) L'anthropisation du Bassin parisien du VIIe au IVe millénaire d'après les analyses polliniques de fonds de vallées : mise en évidence d'activités agro-pastorales très précoces. In: Richard H (ed) Néolithisation précoce. Premières traces d'anthropisation du couvert végétal à partir des données polliniques. Besançon: Presses Universitaires de Franche-Comté (Annales Littéraires de l'Université de Franche-Comté; vol. 777; série "Environnement, sociétés et archéologique"). 7, $11-27$

Lotter A (1999) Late-glacial and Holocene vegetation history and dynamics as shown by pollen and plant macrofossil analyses in annually laminated sediments from Soppensee, central Switzerland. Veget Hist Archaeobot 8:165-184

Louwe Kooijmans LP (1998) Understanding the Mesolithic/Neolithic Frontier in the Lower Rhine Basin, 5300-4300 cal. BC. In: Edmonds M, Richards C (eds) Understanding the Neolithic of NorthWestern Europe. Cruithne, Glasgow, pp 407-427

Lübke H (2005) Spät- und endmesolithische Küstensiedlungsplätze in der Wismarbucht - Neue Grabungsergebnisse zur Chronologie und Siedlungsweise. Jahrbuch 2004, Bodendenkmalpflege in Mecklenburg-Vorpommern 52:83-110

Lüning J (2000) Steinzeitliche Bauern in Deutschland. Die Landwirtschaft im Neolithikum. Universitätsforschungen zur Prähistorischen Archäologie 59. Habelt, Bonn

Makohonienko M, Milecka K, Okuniewska-Nowaczyk I, Nalepka D (2004) Plantago lanceolata L.-Ribwort plantain. In: RalskaJasiewiczowa M, Latałowa M, Wasylikowa K, Tobolski K, Madeyska E, Wright HE jr, Turner C (eds) Late Glacial and Holocene history of vegetation in Poland based on isopollen maps. Krakow, pp 309-315

Meurers-Balke J (1983) Siggeneben-Süd. Ein Fundplatz der frühen Trichterbecherkultur an der holsteinischen Ostseeküste. OffaBücher 50, Wachholtz, Neumünster

Meurers-Balke J, Kalis A (2001) Früh-, mittel- und jungneolithische Landnutzung - archäopalynologische Bearbeitung der WilhelmaTravertine von Bad Cannstatt. Archäologische Berichte 14:631648

Meurers-Balke J, Weninger B (1994) 14C-Chronologie der frühen Trichterbecherkultur im norddeutschen Tiefland und in Südskandinavien. In: Hoika J, Meurers-Balke J (eds) Beiträge zur frühen Trichterbecherkultur im westlichen Ostseegebiet. Wachholtz, Neumünster, pp 239-249

Milojčić V (1960) Präkeramisches Neolithikum auf der Balkanhalbinsel. Germania 38:320-335

Mohr R (1990) Untersuchungen zur nacheiszeitlichen Vegetations- und Moorentwicklung im nordwestlichen Niedersachsen. Vechtaer Arbeiten zur Geographie und Regionalwissenschaft 12. Vechta

Moore PD, Webb JA, Collinson ME (1991) Pollen Analysis, 2nd edn Blackwell, Oxford

Munaut AV (1967) Recherches paleo-ecologiques en Basse en Moyenne Belgique. Acta Geographica Lovaniensia, 6, Louvain

Neumair E (1999) Wang-Grub (Lkr. Freising) Fundchronik für das Jahr 1996, Bayerische Vorgeschichtsblätter, Beiheft 12:35

Nielsen EH (2003) Das Spätmesolithikum und die Neolithisierung in der Schweiz. Archäologische Informationen 26:275-297

O'Connell M (1987) Early cereal-type pollen records from Connemara, western Ireland and their possible significance. Pollen et Spores 29:207-224

O’Connell M, Huang CC, Eicher U (1999) Multidisciplinary investigations, including stable-isotope studies, of thick Late-glacial sediments from Tory Hill, Co. Limerick, western Ireland. Palaeogeogr Palaeoclimatol Palaeoecol 147:169-208 
Peschke P (1983) Pollenanalysen der Schieferkohlen von Herrnhausen (Wolfrathshausener Becken/Obb) - ein Beitrag zum Problem interglazialer Ablagerungen in Oberbayern. Geologica Bavarica 84:107-121

Poska A, Saarse L (2006) New evidence of possible crop introduction to north-eastern Europe during the Stone Age. Veget Hist Archaeobot $15: 169-179$

Puertas O (1999) Premiers indices polliniques de néolithisation dans la plaine littoral de Montpellier (Hérault, France). Bulletin de la Société Préhistorique Française 96:15-20

Raemaekers DCM (1999) The Articulation of a New Neolithic. Archaeological Studies Leiden University 3

Ralska-Jasiewiczowa M, Geel B van (1992) Early human disturbance of the natural environment recorded in annually laminated sediments of Lake Gościąż, central Poland. Veget Hist Archaeobot 1:33-42

Richard H (ed) (2004) Néolithisation précoce. Premières traces d'anthropisation du couvert végétal à partir des données polliniques. Besançon: Presses Universitaires de Franche-Comté (Annales Littéraires de l'Université de Franche-Comté; vol. 777; série "Environnement, sociétés et archéologique"). 7

Richard H, Ruffaldi P (2004) Premières traces polliniques d'influence de l'homme sur le couvert végétal de l'Est de la France. In: Richard $\mathrm{H}$ (ed) Néolithisation précoce. Premières traces d'anthropisation du couvert végétal à partir des données polliniques. Besançon: Presses Universitaires de Franche-Comté (Annales Littéraires de l'Université de Franche-Comté; vol. 777; série "Environnement, sociétés et archéologique"). 7, 117-125

Rösch M (1983) Geschichte der Nussbaumer Seen (Kanton Thurgau). und ihrer Umgebung seit dem Ausgang der letzten Eiszeit aufgrund quartärbotanischer, stratigraphischer und sedimentologischer Untersuchungen. Mitteilungen der Thurgauischen Naturforschenden Gesellschaft 45. Frauenfeld

Rösch M (1985) Ein Pollenprofil aus dem Feuenried bei Überlingen am Ried: Stratigraphische und landschaftsgeschichtliche Bedeutung für das Holozän im Bodenseegebiet. Materialhefte zur Vor- und Frühgeschichte in Baden-Württemberg 7:43-79

Rowley-Conwy P (1995) Making First Farmers Younger: The West European Evidence. Curr Anthropol 36:346-353

Ruffaldi P (1999) Premières traces polliniques de néolithisation des zones de basses altitude de Lorraine (France). Quaternaire 10:263270

Rybníčková E, Rybníček K (1972) Erste Ergebnisse paläogeobotanischer Untersuchungen des Moores bei Vracov, Südmähren. Folia Geobotanica Phytotaxonomica 7:285-308

Rybníčková E, Rybníček K (1996) Czech and Slovak Republics. In: Berglund B, Birks HJB, Ralska-Jasiewieczowa M (eds) Palaeoecological Events During the Last 15000 Years. Wiley, Chichester, pp 472-505

Schütrumpf R (1951) Die pollenanalytische Untersuchung der Verlandungsschichten des Wellsees bei Kiel - ein Beispiel für eine Anwendung der Pollenanalyse in der Praxis. Schriften des Naturwissenschaftlichen Vereins Schleswig-Holstein 25:131-137

Schütrumpf R (1972) Stratigraphie und pollenanalytische Ergebnisse der Ausgrabung des Ellerbek-zeitlichen Wohnplatzes Rosenhof (Ostholstein). Archäologisches Korrespondenzblatt 2:9-16

Schütrumpf R (1988) Moorgeologisch-pollenanalytische Untersuchungen zu der neolithischen Moorsiedlung Hüde I. Göttinger Schriften zur Vor- und Frühgeschichte 23:9-33

Schwabedissen H (1994) Die Ellerbek-Kultur in Schleswig-Holstein und das Vordringen des Neolithikums über die Elbe nach Norden. In: Hoika J, Meurers-Balke J (eds) Beiträge zur frühen Trichterbecherkultur im westlichen Ostseegebiet. Wachholtz, Neumünster, pp 361-401

Seiwald A (1980) Beiträge zur Vegetationsgeschichte Tirols IV: Natzer Plateau-Villanderer Alm. Berichte naturwiss.-medizin. Verein Innsbruck 67:31-72
Smettan HW (1986) Pollenanalytische Untersuchungen zur Vegetations- und Siedlungsgeschichte der Umgebung von Sersheim, Kreis Ludwigsburg. Fundberichte aus BadenWürttemberg 10:367-421

Stika H-P (1991) Die paläoethnobotanische Untersuchung der linearbandkeramischen Siedlung Hilzingen, Kreis Konstanz. Fundberichte aus Baden-Württemberg 16:63-104

Strien H-C, Tillmann A (2001) Die La-Hoguette-Fundstelle StuttgartBad Cannstatt: Archäologie. Archäologische Mitteilungen 14:673-681

Svodobodá H (1997) Die Entwicklung der Vegetation in Südmähren (Tschechien). während des Spätglazials und Holozäns - eine palynologische Studie. Verhandlungen Zoolog.-Botan. Gesellschaft Österreich 134:317-356

Terberger T, Seiler M (2005) Flintschläger und Fischer - Neue interdisziplinäre Forschungen zu steinzeitlichen Siedlungsplätzen auf Rügen und dem angrenzenden Festland. Jahrbuch 2004, Bodendenkmalpflege in Mecklenburg-Vorpommern 52:155183

Tobolski K (1990) Paläoökologische Untersuchungen des Siedlungsgebietes im Lednica Landschaftspark (Nordwestpolen). Offa 47:109-131

Triat-Laval H (1978) Contribution pollenanalytique à l'histoire tardi- et postglaciaire de la végétation de la basse vallée du Rhone. Thèse de doctorat Sciences, Université Aix-Marseille

Tweddle JC, Edwards KJ, Fieller NRJ (2005) Multivariate statistical and other approaches for the separation of cereal from wild Poaceae pollen using a large Holocene dataset. Veget Hist Archaeobot 14:15-30

Vishnu-Mittre (1981) Possible significance of Pre-Neolithic cereal type pollen in South Asia. Proceedings IV international palynological Conference Lucknow (1976-77) 3:291-294

Visset L, Cyprien A-L, Ouguerram A, Barbier D, Bernard J (2004) Les indices polliniques d'anthropisation précoce dans l'Ouest de la France. Le cas de Cerealia, Fagopyrum et Juglans. In: Richard $\mathrm{H}$ (ed) Néolithisation précoce. Premières traces d'anthropisation du couvert végétal à partir des données polliniques. Besançon: Presses Universitaires de Franche-Comté (Annales Littéraires de l'Université de Franche-Comté; vol. 777; série "Environnement, sociétés et archéologique") 7:69-79

Vuorela I (1973) Relative pollen rain around cultivated fields. Acta Botanica Fennica 102:1-27

Wahlmüller N (1985a) Beiträge zur Vegetationsgeschichte Tirols V: Nordtiroler Kalkalpen. Berichte nat.-med. Verein Innsbruck 72:101-144

Wahlmüller N (1985b) Der vorgeschichtliche Mensch in Tirol. Veröffentlichungen des Museum Ferdinandeum Innsbruck 105120

Wasylikowa K, Starkel L, Niedzialkowska W, Skiba S, Stworzewicz E (1985) Environmental changes in the Vistula valley at Pleszów caused by Neolithic man. Przeglad Archeologiczny 33:19-55

Wegmüller S (1976) Pollenanalytische Untersuchungen über die Siedlungsverhältnisse der frühneolithischen Station Egolzwil 5. In: Wyss R (ed) Archaeologische Forschungen. Das jungsteinzeitliche Jäger-Bauerndorf von Egolzwil 5 im Wauwilermoos. Zürich, pp $141-150$

Welten M (1982) Vegetationsgeschichtliche Untersuchungen in den westlichen Schweizer Alpen: Bern-Wallis. Denkschriften der Schweizerischen Naturforschenden Gesellschaft 95. Basel

Wendorf F, Schild R, El Hadidi N, Close AE, Kobusiewicz M, Wieckowska H, Issawi B, Haas H (1979) Use of Barley in the Egyptian Late Paleolithic. Science 205:1341-1347

Wendorf F, Schild R, Close AE, Donahue DJ, Jull AJT, Zabel TH, Wieckowska H, Kobusiewicz M, Issawi B, El Hadidi N (1984) New Radiocarbon Dates on the Cereals from Wadi Kubbaniya. Science 225:645-646 
Wiethold J (1998) Studien zur jüngeren postglazialen Vegetationsund Siedlungsgeschichte im östlichen Schleswig-Holstein. Universitätsforschungen zur prähistorischen Archäologie 45. Habelt, Bonn

Willerding U (1980) Zum Ackerbau der Bandkeramiker. Materialhefte zur Ur- und Frühgeschichte Niedersachsens 16:421-456

Wischenbarth P (1995) Spätmesolithische und linearbandkeramische Funde der Riss-Lech-Platte und deren Interpretation. Germania $73: 1-40$
Zeist W van, Palfenier-Vegter RM (1983) Seeds and fruits from the Swifterbant S3 site. Palaeohistoria 23:105-168

Zeist W van, Wasylikowa K, Behre K-E (eds) (1991) Progress in Old World Palaeoethnobotany. Balkema, Rotterdam/Brookfield

Zvelebil M (1996) The agricultural frontier and the transition to farming in the circum-Baltic region. In: Harris DR (ed) The origin and spread of agriculture and pastoralism in Eurasia. UCL Press, London, pp 323-345 